\title{
ADVERBIALS WITH ADJECTIVAL BASIS IN BRAZILIAN PORTUGUESE AND THEIR FREQUENCY IN SPOKEN AND WRITTEN LANGUAGE
}

\author{
KATHARINA GERHALTER ${ }^{1}$, STEFAN KOCH ${ }^{2}$
}

\begin{abstract}
Adverbials with Adjectival Basis in Brazilian Portuguese and Their Frequency in Spoken and Written Language. The present paper focuses on the use of adverbs with an adjectival lexical base in spoken and written presentday Brazilian Portuguese. We compare the frequencies of three different types of adverbials: adverbs in -mente (e.g. absolutamente), adjective-adverbs (e.g. alto in falar alto 'speak loudly') and prepositional phrases with adjectives as the postprepositional element (e.g. de novo), the latter being the main focus of this study. The analysis is based on the Discurso \& Gramática-corpus, which consists of oral interviews of 170 informants and their written texts on the same topic as the one in the interviews. The data shows that prepositional phrases are less frequent (in terms of type and token frequency) than adjective-adverbs and adverbs ending in -mente. Regarding the difference between spoken and written language, adverbs in -mente occur remarkably more often in written texts while adjective-adverbs are more frequent in spoken language. Prepositional phrases, instead, occur equally in both codes. Finally, we draw the conclusion that prepositional phrases form a small but stable inventory of lexicalised forms, which are not marked for any code.
\end{abstract}

Keywords: adverbials, adverbial locutions, adjective-adverbs, adverbs ending in -mente, Brazilian Portuguese, frequency, written vs. spoken language.

1 Katharina GERHALTER is currently working as a Post-Doc at the University of Graz, Institut für Romanistik - Department of Romance Studies. Previously she was a researcher within the FWFproject "Open Access Database: Adjective-Adverb Interfaces in Romance" (<https://gams.unigraz.at/context:aaif >), funded by the Austrian Science Fund (FWF ORD 66-VO, 2017-2020) and directed by Martin Hummel. This project was a cooperation between the Department of Romance Studies and the Austrian Centre for Digital Humanities at the University of Graz. EMail: Katharina.Gerhalter@uni-graz.at.

2 Stefan KOCH is currently a Post-Doc within the FWF-project "The Third Way" on prepositional adverbials in the Romance languages at the University of Graz, Institut für Romanistik Department of Romance studies. This project is funded by the Austrian Science Fund (FWF P 30751, 2018-2021) and directed by Martin Hummel at the University of Graz ( $<$ https://adjectiveadverb.uni-graz.at/en/projects/the-third-way-2018-2021/>). Previously he worked at the universities of Erlangen-Nuremberg (2009-2012; 2017-2019) and Munich (2012-2016). E-Mail: Stefan.Koch@uni-graz.at. 


\begin{abstract}
REZUMAT. Adverbialele cu bază adjectivală în portugheza din Brazilia şi frecvența lor în limba scrisă şi în cea vorbită. Acest studiu are în vedere folosirea adverbelor cu bază lexicală adjectivală în portugheza braziliană modernă, scrisă şi vorbită. Mai precis, este vorba despre compararea frecvenței a trei tipuri: adverbe în -mente (absolutamente), adjective adverbializate (alto în sintagme precum falar alto) şi adjective cu prepoziții (de novo), cel din urmă tip constituind obiectul principal al acestui studiu. Analiza datelor se bazează pe corpusul Discurso \& Gramática, ce conţine o serie de interviuri cu 170 de informatori şi textele scrise corespondente. Datele arată că adverbele cu prepoziţie sunt mai puţin numeroase (ţinând cont frecvențele type şi token) decât adjectivele adverbializate sau decât adverbele în -mente. În ceea ce privește diferența dintre limba vorbită şi cea scrisă, adverbele în -mente apar mult mai des în texte scrise, în timp ce adjectivele adverbializate sunt mai numeroase în limba vorbită. În schimb, structurile cu prepoziţie sunt reperabile în amândouă registrele. Din faptele de limbă investigate, reiese că locuțiunile adverbiale fac parte dintr-un inventar restrâns, dar stabil de forme lexicalizate, care nu caracterizează un registru anume.
\end{abstract}

Cuvinte-cheie: adverbe, locuţiuni adverbiale, adjective adverbializate, adverbe in -mente, portugheza braziliană, frecvenţă, limbă scrisă vs vorbită.

\title{
1. Introduction
}

This paper focuses on three types of adverbials in Brazilian Portuguese $(=$ BP) that are morphosyntacticly based on an adjective as a root: adjective-adverbs (henceforth AA) such as alto in fala alto 'speak loud(ly)' (conversion), adverbs in -mente such as absolutamente 'absolutely' (derivation) and prepositional phrases such as Pt. de novo 'again' (analytic formation; frequently referred to as "adverbial locutions" or "prepositional locutions", Pt. locuções adverbiais). We will address some claims made within the project The Third Way: Prepositional Adverbials from Latin to Romance (see footnote 2), which aims at documenting and analysing a specific type of those prepositional phrases, i.e. adverbials of the pattern "preposition + adjective" (= PA-adverbials henceforth; cf. Hummel 2019a and 2019b; Hummel et alii 2019). We will focus specifically on some of the project's working hypotheses concerning the marginalized status of PA in comparison to their morphological counterparts, adverbs in -mente and adjectiveadverbs, as well as the differences between spoken and written language.

This paper is structured as follows: section 2 features the theoretical background on adjective-based adverbials, a short overview of the state of the art and our hypotheses. Section 3 describes the corpus used for the empirical analysis in sections 4 and 5, which offer a quantitative overview of the data (4) and specifically analyse the differences between spoken and written language (5). Section 6 contains conclusions. 


\section{Theoretical Background, State of the Art, and Hypotheses}

The category 'adverb' is generally difficult to define or to delimit because of its heterogeneity in both form and function. ${ }^{3}$ Basically, adverbs can be defined as modifiers: "Modification is a linguistic function that refers to a semantic change operated on a primary unit, e.g. a word or a sentence" (Valera and Hummel 2017: 1). In the case of adverbs, this means that they modify the proposition of a sentence and, more often, the action or event expressed by a VP. In this sense, adverbs are modifiers that, by themselves, denote a circumstance such as time, place, manner, intensity, etc. (Bechara 2009: 356).

The most frequently used adverbs in BP have own lexical forms, which are not derived or formed by word-formation processes: aqui 'here', bem 'well', hoje 'today', não 'no, not', là 'there', talvez 'maybe', etc. (Bechara 2009: 356). These lexical adverbs are not tackled in the present study nor annotated in the D\&G corpus. Our study concerns only adverbs that in some way or another are based on an adjectival root. The relevant morphosyntactic processes to create adverbs based on adjectives are therefore the following:

\section{a) Adjective-adverbs}

Adjectives converted into adverbs (adjective-adverbs = AA, conversion). The adverbial function is not morphologically marked. The bare adjective is used in an adverbial function and marked solely by the syntactic position, for example: fala claro na hora da sua defesa 's/he speaks clear(ly) [...]' (Bechara 2009: 364; our emphasis and translation). According to Hummel (2014), adjectiveadverbs belong to the oral Romance tradition.

\section{b) Adverbs ending in -mente}

Derived adverbs "adjective (derivational base $=$ root $)+a$ (fossilised marker of the feminine form) + derivational suffix -mente (overt marker of the grammatical status of the word as an adverb)". In more recent publications, adverbs in -mente are considered as a product of the intrusion of written forms into spoken Romance (cf. Bauer 2001; 2003; Grübl 2018). This diachrony leaves its traces even in present-day Romance, confirmed for Spanish, for example, by Kortschak \& Hummel (2018: 38), who show that adverbs in -mente are more frequent in formal contexts and in speech that is closer to the written tradition.

\footnotetext{
${ }^{3}$ For a theoretical overview on Portuguese adverbs cf. Martelotta (2012); for an etymological perspective on Romance adverbs in general cf. Chircu (2008).
} 


\section{c) Prepositional adverbials}

Phrases or locutions formed with "preposition + adjective" (= PA): de novo (analytic formation). The adjective may also be inflected (gender and number): às claras 'visibly'. For a bibliographical overview on Portuguese PA-adverbials, see Hummel et alii (2019: 1105-1110). However, PA is often not considered as an independent means of forming adverbs or even reinterpreted as PN (preposition + noun): "em breve (subentende-se tempo)" 'shortly' (Bechara 2009: 359), since adverbial locutions seem to be mainly formed after the PN pattern, such as com efeito 'indeed', de graça 'for free', às vezes 'sometimes', em silêncio 'in silence', na verdade 'in fact, in truth', etc. (cf. Bechara 2009: 359; see also the examples in Chircu 2006: 28). Even combinations of the type "preposition + adverb" (P + Adv.) exist: por agora 'for now', até então 'until then', desde cedo 'from early on' (Bechara 2009: 357). On the discussion of the general combinability of prepositions with words other than nouns see e.g. Sicherl and Žele (2015).

Adjective-adverbs are the fuzziest category of the three types since the interfaces between the functional categories 'adjectives' and 'adverbs' are somewhat blurred in the Romance scenario. Some positions are ambiguous (e.g. secondary predicates) and adjective-adverbs can also occur inflected (cf. Silvestri 2017: 31 for Southern Italian dialects). The following example shows that also in BP adjective-adverbs (apressados 'rushed' in 1) can agree with the subject (eles 'they'), but still describe the manner in which the action of the verb (saem 'leave') is conducted:

(1) ela estava saindo pra ir trabalhar... de manhã cedo...e geralmente de manhã cedo os ônibus... né? são muito cheios e são/eles saem muito apressados (Flávia, f, 19, Informantes do Ensino Médio (de 18 a 20 anos), 1993, Rio de Janeiro, parte oral; our bolds)

In these cases, a clear-cut distinction between adjective and adverb may not be possible. Bechara (2009: 364-365) argues for the inflectional criterium: in the case of Eles vendem muito cara a fruta 'They sell the fruit very expensive' (adjective) vs. Eles vendem caro a fruta 'They sell the fruit very expensively' (adverb), the agreeing form cara 'expensive' represents the adjective, the nonconcordant default form the adverb. In concordance, Basílio (2002: 83-84) denies inflected forms the status of adverbs. Nevertheless, data from BP and Southern Italian dialects show that the inflected form can still be considered adverbial (for details cf. Hummel 2017; Koch and Vecchia in prep.). Therefore, we consider both, agreeing and non-agreeing forms, as adverbs and as such they are extracted from the corpus. 
The aforementioned project The Third Way raises the question of the frequency of PA in present-day language. According to this, our first hypothesis will be the following:

PA exist, but are less frequent than the other types, since historically they have been marginalized by adverbs in -mente (Hummel et alii 2019: 1119 ), being now the least productive adverbial of the three types in BP.

Furthermore, we take a second hypothesis of the project and put it to a test:

PA today appear evenly in written and spoken language. This hypothesis goes along with the distributional pattern postulated by the project The Third Way (cf. Hummel 2018: 7; Hummel et alii 2019: 1116).

\section{The corpus}

In order to measure the frequency of the different adverbials, over 4,000 examples in the Brazilian corpus Discurso \& Gramática (= D\&G corpus) were analysed. This corpus was created by the research group Discurso \& Gramática ${ }^{4}$ from 1991 to 1998. It consists of spoken and written texts in BP. A total of 171 informants were interviewed in the cities of Rio de Janeiro, Rio Grande do Norte, Juiz de Fora, Natal and Niterói. The selection of informants was based on several pre-defined categories (sex, age, level of education) in order to enable sociolinguistic analysis. The interviews consist of the same five topics for all informants: a personal story (narrativa de experiência pessoal), a retold story (narrativa recontada), a description of a place (descrição de local), an instruction on a process (relato de procedimento, e.g. how to prepare a certain recipe) and a personal opinion on some controversial topic (relato de opinião). The recordings were transcribed by the research group Discurso \& Gramática using standard orthography and some basic symbols for pauses, question prosody, truncations, etc. Additionally, after the oral interviews, each informant wrote (by hand) five texts on the exact same topics, which were also added to the corpus (computer-transcribed, without correcting errors and without modifying the original orthography of the informants).

\footnotetext{
4 The research group Discurso \& Gramática (= D\&G) was founded in the 1990ies by Sebastião Votre. The group has head offices in three Brazilian federal universities: UFRJ (Universidade Federal do Rio de Janeiro), UFF (Universidade Federal Fluminense) and UFRN (Universidade Federal do Rio Grande do Norte). The compilation of the corpus D\&G was directed by Sebastião Votre (UFRJ), Mariangela Rios de Oliveira (UFF) and Maria Angélica Furtado da Cunha (UFRN). The group carries out research on a variety of topics in usage-based linguistics, especially on linguistic change.
} 
In the course of the project Open-Access Database: Adjective-Adverb Interfaces in Romance (= AAIF; see footnote 1 ), the whole D\&G corpus was integrated into the database and the adverbials were manually tagged: ${ }^{5}$ each instance of an adjective-adverb, adverb in -mente and PA was lemmatized and annotated using the annotation tool of the AAIF-Project, which contains several pre-defined morphosyntactic and semantic categories (Gerhalter et alii 2018). Consequently, this updated version of the D\&G corpus offers a systematic and complete labelling of these adverbials (-mente, AA and PA), which enables a quantitative analysis of the data on a large scale. The whole corpus and the annotations are publicly available and can be queried via a search interface (Votre et alii 2020), which also permits filtering spoken from written examples.

The D\&G corpus consists of $\sim 384,900$ words; $\sim 303,400$ words are spoken and $\sim 81,500$ are written. ${ }^{6}$ The $D \& G$ corpus is thus not balanced in terms of the size of written and spoken texts, since most informants (especially the youngest children and adults from the alphabetisation class) wrote shorter texts, which mostly resumed the oral interviews. This might be attributed to the fact that written texts generally tend to densify information whereas spoken conversations consist additionally of many phenomena that may be considered unnecessary in terms of information packaging, such as repetitions, hesitation phenomena, autocorrections, phatic discourse markers, turn-taking signals, etc. (cf. in general Maas 2010; Koch and Oesterreicher 2011; Coulmas 2013). Nevertheless, the corpus design permits, for example, testing of whether informants use the same types of adverbs in their written texts as they do in the spoken interviews (for example: do they add more adverbs in -mente when writing on the same topic they have been talking about before?).

Previous to the AAIF-project, adverbials in the D\&G corpus have already been analysed in an eclectic manner in different publications, but never in a holistic approach. For example, Barbosa (2006) studied adjective-adverbs in the D\&G corpus of Rio de Janeiro, and Vidal (2009) adverbs in -mente in the D\&G corpus of Natal. Furtado da Cunha (2012) analysed the distribution of the negation adverb não in the complete D\&G corpus. Hummel (2017) searched the corpus for inflected adverbs such as in vamos diretos 'we go directly', todas contentes 'totally happy', bastantes grandes 'relatively big' or muitas boas 'very good'. Recently, members of the still active $D \& G$ research group used the corpus to

5 The originally published pdf-versions and the transcription system are online at: $<$ https://discursoegramatica.wordpress.com/corpus/>. With the friendly permission of the head researchers of the Discurso \& Gramática research group, the plain texts were integrated into the AAIF-database by transforming the text parts into a reusable and storable xml/TEI format.

${ }^{6}$ Relying on the word-counting programme Voyant (resulting in 391,000 words) and further adapting by eliminating metatexts like $E$ : for entrevistador 'interviewer' in the spoken subcorpus. 
analyse the multifunctional adverbs enfim 'finally' (Azevedo 2018) and aliás 'indeed, furthermore' (Ramos 2018), as well as assim 'so' and adverbials formed by a preposition and a noun. ${ }^{7}$

Some comparative studies have been conducted focussing on the comparison of adverbs in -mente and adjective-adverbs. For example, Campos (2019) compared constructions like Maria falou claro and Maria falou claramente 'Mary spoke clear(ly)' in BP. However, her data was taken from other corpora than the D\&G corpus.

By contrast, the present paper includes a third adverbial type: the PApattern. The tagging of all examples of PA, -mente and AA during the AAIFProject permits an exhaustive analysis of those adverbials in the D\&G corpus. The quantifiers muito 'very, many', todo 'totally', bastante 'relatively', meio 'semi-' were excluded from the present study since they only exist as adjective-adverbs and never form derivations with -mente. ${ }^{8}$ The present paper is a first (and mainly quantitative) approach to the data and invites for further and more fine-grained analyses.

\section{Quantitative Overview}

Table 1 shows an overview of the three morphosyntactic alternatives, prepositional phrases of the type "preposition + adjective" (= PA), adjectiveadverbs and adverbs in -mente, found in the corpus. The lexical-morphosyntactic types, which are based on the same adjectival root (the same base lexeme), are placed in the same line (therefore forming a lexical group).

Table 1 shows only those lexical groups that produce a PA-pattern in the corpus and the respective - documented or possible (then shown in parenthesis) - AA- or -mente-correlates. The whole inventory of all adverbs in -mente, adjective-adverbs and PA-forms (also including the groups that only consist of -mente and/or AA) can be consulted online on the corpus' website (see footnote 1).

\footnotetext{
7 Investigations on the adverb assim and on adverbials of the type "preposition + noun" (com certeza, etc.), both based on the D\&G corpus, were presented at the D\&G congress in 2017 but have not yet been published.

8 Those examples of the quantifiers muito, bastante, todo/tudo and meio which modify an adjective or adverb (muito contente, meio chata, ...) were analysed by Hummel (2017). They are included in the AAIF-Database, whereas their occurrences as manner or sentence adverbials were not annotated, which is another reason to exclude them from the present analysis (incompleteness). In addition, even only in their function as modifiers of adjectives or adverbs, they are very frequent and already deliver 1,889 examples out of a total of 4,922 adjective-adverbs. Therefore, the comparison with PA and -mente in this paper is limited to the remaining 3,033 examples of AA.
} 
Table 1. List of PA-adverbials and their correlates in the D\&G corpus

\begin{tabular}{|cc|cc|cc|}
\hline \multicolumn{2}{|c|}{ PA (formation-type) } & \multicolumn{2}{c|}{ AA (formation-type) } & \multicolumn{2}{c|}{-mente (formation-type) } \\
\hline tokens & $\begin{array}{c}\text { lexical- } \\
\text { morphosyntactic type }\end{array}$ & tokens & $\begin{array}{c}\text { lexical- } \\
\text { morphosyntactic type }\end{array}$ & tokens & $\begin{array}{c}\text { lexical- } \\
\text { morphosyntactic type }\end{array}$ \\
\hline 5 & a sério & 8 & sério & 1 & seriamente \\
$2 / 1$ & pro alto/por alto & 22 & alto & 1 & altamente \\
1 & em breve & 1 & breve & 1 & brevemente \\
1 & ao certo & 110 & certo & 7 & certamente \\
$2 / 2$ & às claras/em claro & 18 & claro & 1 & claramente \\
1 & por igual & 3 & igual & 1 & igualmente \\
4 & de leve & 1 & leve & 1 & levemente \\
2 & de primeiro & 152 & primeiro & 12 & primeiramente \\
1 & a sós & 1291 & só & 26 & somente \\
5 & ao vivo & 1 & vivo & - & - \\
1 & em finas & 1 & fino & - & - \\
2 & por completo & - & - & 19 & completamente \\
3 & em comum & - & - & 1 & comumente \\
2 & em especial & - & - & 6 & especialmente \\
1 & ao extremo & - & - & 3 & extremamente \\
$16 / 2$ & em geral/no geral & - & - & 70 & geralmente \\
5 & de imediato & - & - & 7 & imediatamente \\
132 & de novo & - & - & 49 & novamente \\
22 & por último & - & - & 11 & ultimamente \\
1 & a fundo & - & - & $(5)$ & (profundamente) \\
1 & de perto & - & (perto) & - & - \\
2 & em branco & - & (branco) & - & - \\
1 & em público & - & - & - & (públicamente) \\
2 & em vão & - & - & - & (vãmente) \\
\hline & & & &
\end{tabular}

The specific number of triplets (for example, the group a sério, sério, seriamente 'seriously'), doublets (for example, the group por completo, completamente 'completely'), or lexical groups formed by one single formationtype (only -mente, only PA or only AA) are shown in table 2.

Table 2. Distribution of root lexemes (221 lexical groups)

\begin{tabular}{cccc}
\hline \multicolumn{2}{c}{ Lexical groups } & Constituting formation-type(s) & Examples \\
\hline 126 & $57 \%$ & only -mente & estupidamente \\
47 & $21 \%$ & only AA & mesmo \\
24 & $11 \%$ & doublets AA + -mente & tranquilo + tranquilamente \\
9 & $4 \%$ & triplets AA + -mente + PA & a sério + sério + seriamente \\
8 & $4 \%$ & doublets -mente + PA & em geral + geralmente \\
5 & $2 \%$ & only PA & em vão \\
2 & $1 \%$ & doublets AA + PA & vivo + ao vivo \\
\hline Total 221 & $100 \%$ & &
\end{tabular}


Figure 1 visualises the distribution of the base lexemes (lexical groups) as shown in table 2 :

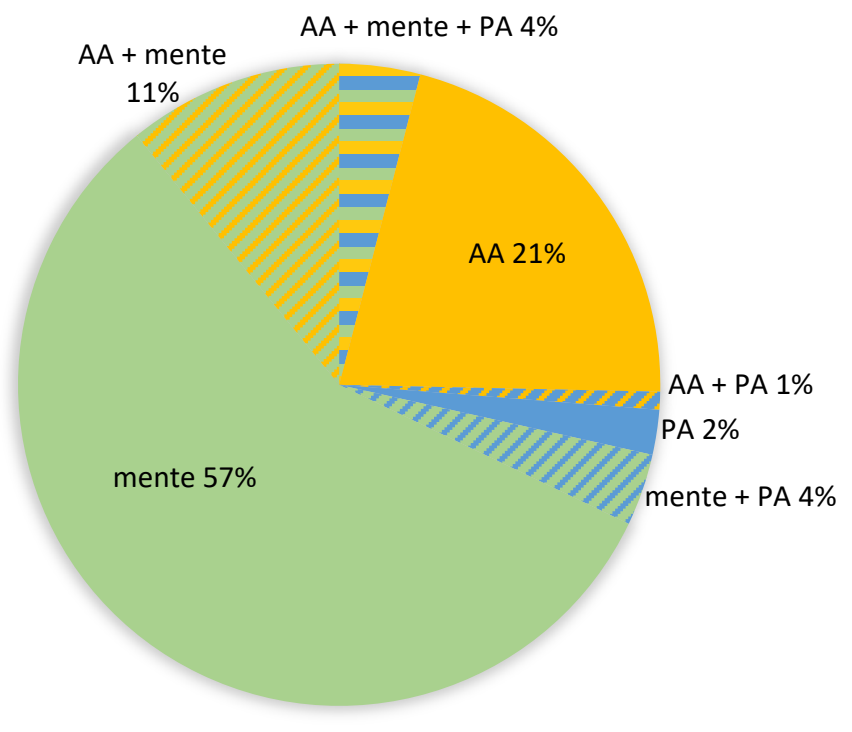

Figure 1. Distribution of base lexemes according to lexical groups $(\mathrm{N}=221)$.

Only a small proportion (4\%) of base lexemes (adjectival roots) appears in triplets, whereas most base lexemes are documented only as adverbs in -mente or as adjective-adverbs. This may hint to a lexical differentiation in terms of the selection of one morphosyntactic type or another (-mente or AA), depending on the base lexeme (adjectival root). This is less the case for the PA-pattern (see figure 1), which mostly (79\%) appears in groups with -mente, AA, or both. The result is consistent with the initial hypothesis by Hummel (2019a, 2019b) that PA appear as systematic alternatives to AA and/or -mente, insofar as alternatives also exist for the remaining "single" PA-groups in BP, which are not documented in the corpus (for example, em vão + vãmente 'in vain'), as shown in table 1 (alternatives in parenthesis).

Henceforth, the lexical groups will be split up and every single correlate will be counted as one type, more precisely, as one lexical-morphosyntactic type (for example, certamente $=1$ type, a certo $=1$ type, completamente $=1$ one type, por completo $=1$ type, etc.) and every single instance of these types is counted as one token (see also token numbers in table 1).

Table 3, instead, contains the total of lexical-morphosyntactic types by formation-type: 
Table 3. Relative frequency of the formation-types

\begin{tabular}{cccc|c}
\hline & AA & - mente & PA & total \\
\hline types & 76 & 167 & 24 & 267 \\
& $28 \%$ & $63 \%$ & $9 \%$ & $100 \%$
\end{tabular}

For example, it can be deduced that the formation-type -mente is the lexically most differentiated, since 167 different -mente-adverb-lexemes were documented in the corpus, whereas PA shows less lexical variation (24 different lexemes).

The counting of tokens in table 4 is based on the examples documented for each formation-type and shows that adjective-adverbs are used much more frequently than PA and adverbs in -mente:

Table 4. Relative token frequency per formation-type

\begin{tabular}{cccc|c}
\hline & AA & -mente & PA & total \\
\hline tokens & 3,033 & 1,111 & 220 & 4,364 \\
& $70 \%$ & $25 \%$ & $5 \%$ & $100 \%$
\end{tabular}

Comparing tables 3 and 4, adjective-adverbs make up 70\% of the total tokens $(3,033$ examples out of a total of 4,364 annotated examples in the corpus), but correspond to only $28 \%$ of the lexical-morphosyntactic types, meaning the lexical differentiation within the formation-type AA is relatively low. For example, the lexical-morphological type só (AA) alone appears 1,291 times (see table 1). Therefore, already $43 \%$ of all AA-tokens $(1,291$ out of 3,033$)$ correspond to this lexical type. Other highly frequent AA are mesmo 'even' (557 tokens), bom (as discourse marker 'well', 192 tokens) pronto 'ready' (116 tokens) and direito 'directly' (81 tokens).

The formation-type -mente, on the other hand, amasses only $25 \%$ of the total tokens, but makes up $63 \%$ of the lexical-morphosyntactic types. Therefore, the lexical differentiation of this formation-type is much higher than in the case of adjective-adverbs. The most frequently used adverbs in -mente are realmente 'really' (156 tokens), principalmente 'primarily' (72 tokens), totalmente 'totally' (72 tokens) and geralmente 'generally' (70 tokens). Approximately one half of the adverbs in -mente (86 out of 167 lexical types) occur only once, like estupidamente 'stupidly', constantemente 'constantly' and disfarçadamente 'disguisedly'. This indicates that the formation-type -mente is the lexically most productive one (cf. also Chircu 2006: 26), since it is also the preferred type for less frequent lexical roots, e.g. burramente 'donkey-like', espiritualmente 'spiritually', futuramente 'in the future', ingenuamente 'naively', liturgicamente 'liturgically', and torrencialmente 'torrentially' (cf. as well Raposo et alii 2013: 331). 
The pattern "preposition + adjective" generally is the less frequent formation-type, it makes up only $5 \%$ of all the tokens and only $9 \%$ of the lexicalmorphosyntactic types. However, the overall token number is distorted by the high token frequency of one single lexical-morphosyntactic type: de novo 'again' occurs 132 times (see table 1). Hence, out of a total of 220 PA-tokens (see table 4 ), more than a half correspond to de novo. The remaining lexical types for PA are rather scarce in terms of their number of tokens: por último 'in the end' (22 tokens), em geral 'in general' (18 tokens), a sério 'seriously' (5 tokens), etc.

Overall, the type-token ratio (based on tables 3 and 4) is 39 tokens per lexical type in the case of adjective-adverbs, but only 6 tokens per lexical type in the case of -mente. This means that a lexical type in the AA- formation-type appears, on average, 39 times in the corpus, whereas lexical types for adverbs in -mente appear, on average, only 6 times. The ratio for PA is slightly higher than for-mente, with 9 tokens per lexical type. However, this is due to the high frequency of de novo. The remaining 23 types (em geral, por último, de leve 'lightly', etc.) sum up only 88 tokens and therefore make up an average ratio of 4 tokens per type, which then is lower than the ratio for -mente.

Hypothesis 1 can therefore be considered as valid. PA is less frequent than -mente and AA, both in terms of lexical types per formation-type and in terms of overall tokens. Only one PA (de novo) produces more than half of the PA-tokens, the others are marginal.

\section{Spoken vs. written data}

In order to analyse hypothesis 2 , in this section we focus on possible differences between spoken and written language in the D\&G corpus with respect to the frequency of the analysed adverbials. The relevant literature on the subject (cf. Hummel 2019a: 131; Hummel et alii 2019: 1116, 1120) suggests a more or less even use of the PA-pattern in spoken and written language. This does not exclude, of course, a possible lexical differentiation between the two codes, i.e. the predominant existence of certain PA in written texts, while other PAs are predominantly used in spoken language.

In table 5 we therefore split the general token frequencies of $\mathrm{AA}$,-mente and PA (as previously shown in table 4) into a spoken and a written subcorpus. Since the written corpus is much smaller, we calculate on the basis of occurrences per 100,000 words (normalized frequency).

In total, adverbials are nearly as frequently used in the spoken corpus (normalized frequency: 1,115) as in the written one (normalized frequency: 1,204) (see also figure 2). Nevertheless, the different formation-types differ remarkably depending on the code, as shown in figure 2 and figure 3 (both based on the numbers in table 5). 
Table 5. Tokens in the spoken and written subcorpora

\begin{tabular}{c|lccc|c} 
& & AA & $-m e n t e$ & PA & total \\
\hline \multirow{2}{*}{ Spoken } & Number of tokens & 2,503 & 714 & 166 & 3,383 \\
& Distribution & $74 \%$ & $21 \%$ & $5 \%$ & $100 \%$ \\
& Ratio per 100,000 words & 824.98 & 235.33 & 54.71 & $1,115.03$ \\
\hline \multirow{2}{*}{ Written } & Number of tokens & 530 & 397 & 54 & 981 \\
& Distribution & $54 \%$ & $40 \%$ & $6 \%$ & $100 \%$ \\
& Ratio per 100,000 words & 650.30 & 487.11 & 66.26 & $1,203.68$ \\
\hline \multirow{2}{*}{ Total } & Number of tokens & 3,033 & 1,111 & 220 & 4,364 \\
& Distribution & $70 \%$ & $25 \%$ & $5 \%$ & $100 \%$
\end{tabular}

\begin{tabular}{l|l|l|l} 
written & AA 650.3 & mente 487.11 & PA 66.26
\end{tabular}

oral

\begin{tabular}{l|l} 
AA 824.98 & mente 235.33 PA 54.71
\end{tabular}

$\begin{array}{lllllll}0 & 200 & 400 & 600 & 800 & 1000 & 1200\end{array}$

Figure 2. Normalized token frequency (ratio per 100,000 words) of the three formation-types for each subcorpus (oral/spoken and written).

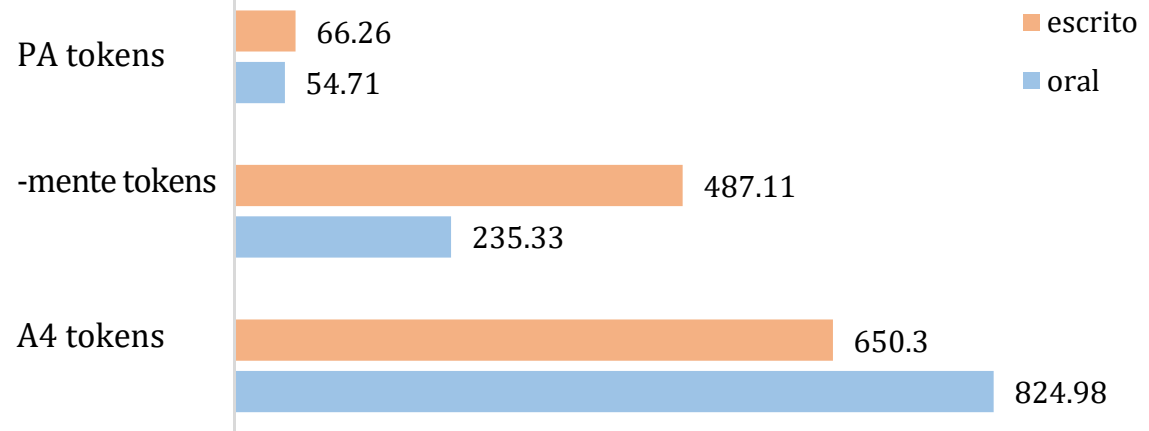

Figure 3. Normalized token frequency (ratio per 100,000 words) in the written (orange) and oral/spoken (blue) subcorpus for each formation-type.

Adverbs of the AA-type are the most frequent ones as seen in figure 2, 3 , and in table 5 , both in spoken and written language, which might be somewhat unexpected for the written part, since adjective-adverbs are generally considered to belong to the oral tradition. These findings might be in concordance with the 
analysis by Alarcón Neve (2019), who shows that the proportion between AA and adverbs in -mente does not only depend on the code but also on register and style: adjective-adverbs are more frequent than adverbs in -mente in informal and spontaneous texts written by school children (a text type comparable to the D\&G corpus). On the other hand, according to Alarcón Neve (2019), adverbs in -mente are predominant in more formal and literary text types produced by the same children. This tendency is also confirmed by data from another predominantly literature-based corpus: the corpus used for the publication Sintaxis histórica de la lengua española, vol. III (ed. by Company Company 2014a). Indeed, this data shows a higher number of adverbs in -mente (cf. Company Company 2014b) compared to adjective-adverbs (cf. Hummel 2014) ${ }^{9}$ when confronting the results of both chapters.

Returning to our data from the D\&G corpus, within the AA-formationtype, the ratio per 100,000 words in the spoken corpus is still higher $(824.98$ tokens) than in the written corpus (650.3 tokens), an increase of $26.9 \%$. Furthermore, $44 \%$ of the AA-forms appear in written texts, but $56 \%$ in the spoken corpus, still considering the normalised numbers.

As for adverbs in -mente, the difference between the spoken and written subcorpus is even more pronounced, since the number of tokens in the written texts is twice as high as in the spoken ones. $33 \%$ of adverbs in -mente $(235.33$ tokens per 100,000 words) appear in the spoken corpus, in contrast to $67 \%$ (487.11 tokens) in the written texts, which corresponds to an increase of $107 \%$. Therefore, code-based variation is most salient for adverbs in -mente. The higher frequency of adverbs in -mente in the written corpus seems to approximately compensate the lower frequency of AA in this subcorpus (compared to AA in spoken corpus, see figure 2).

PA-adverbials are slightly more frequent in the written corpus: $45 \%$ (corresponding to 54.71 tokens per 100,000 words) occur in the spoken subcorpus and 55\% (66.26 tokens) in the written subcorpus, still representing a rise of $21.1 \%$. Whereas the difference is clear for adverbs in -mente, in the case of PA this difference may, at a first glance, not seem significant.

However, conducting a fisher test on the normalised tokens for each formation-type in the written and the spoken part of the corpus, there are clear tendencies, at least regarding adverbs in -mente and adjective-adverbs. While adverbs in -mente occur with a significantly higher frequency in written texts (487 tokens per 100,000 words) than in spoken language (235), resulting in a pvalue of $2.2 \times 10^{-16}$, adjective-adverbs show significantly more tokens per 100,000

\footnotetext{
9 The examples in Hummel (2014), adjective-adverbs and prepositional adverbials, are included in the AAIF-database (see footnote 1).
} 
words in spoken language (825) than in written language (650; $p=5.304 \times 10^{-06}$ ), although still being more frequent also in written texts than -mente. The difference between occurrences of PA in written and spoken language, always per 100,000 words (66 vs. 55), is far less pronounced and is on the verge of insignificance ( $p=0.3632)$, which is only slightly below the minimum $p$-value of 0.5 in a calculation with a confidence interval of $95 \%$. Thus, the PA-pattern does not even nearly reach the significance levels of -mente and AA in terms of a clear-cut distinction in their preferred use in either written or spoken language; there is only a slight tendency towards written texts.

Concerning the lexical differentiation (number of different lexical types per formation-type), we counted the different types both in the spoken and written subcorpus, as shown in table 6 (which splits up the data presented above in table 3).

Table 6. Lexical types per formation-type in the spoken and written subcorpus

\begin{tabular}{c|cccccc|cc}
\multicolumn{2}{c}{} & \multicolumn{2}{c}{ AA } & \multicolumn{2}{c}{-mente } & \multicolumn{2}{c}{ PA } & \multicolumn{2}{c}{ total } \\
\hline spoken & 63 & $35 \%$ & 96 & $49 \%$ & 19 & $10 \%$ & 195 & $100 \%$ \\
written & 37 & $21 \%$ & 126 & $70 \%$ & 17 & $9 \%$ & 180 & $100 \%$ \\
\hline entire corpus & 76 & $30 \%$ & 167 & $61 \%$ & 24 & $9 \%$ & 273 & $100 \%$
\end{tabular}

Figure 4 shows the overlapping of lexical types for each formation-type in the spoken and written corpora, meaning the number of lexicalmorphosyntactic types that occur in both subcorpora or only in one of the two.

$\varpi$ only oral $\square$ both $\square$ only written

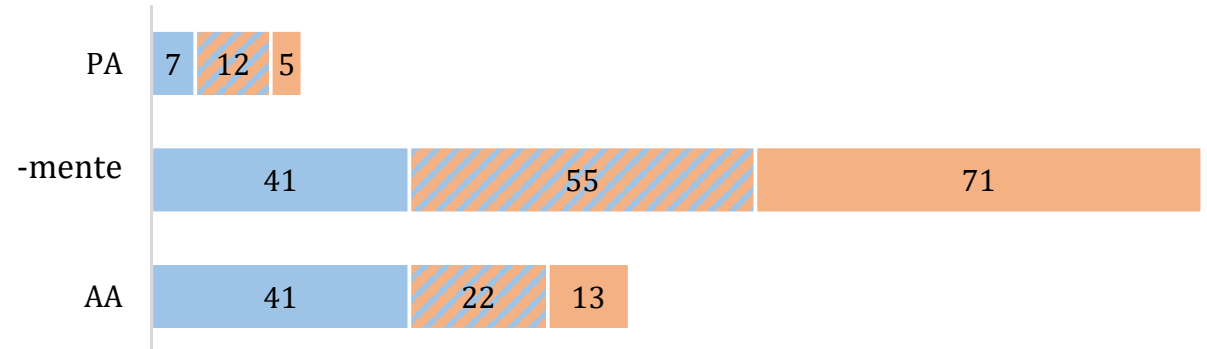

Figure 4. Distribution of lexical types per formation-type in written and/or spoken subcorpus.

Since it is impossible to consider the non-balanced corpus sizes when counting different lexical types - as we did indeed for the tokens (normalized frequency)-, table 6 and figure 4 compare the type-frequencies of the much 
larger spoken subcorpus to the smaller written subcorpus. Nevertheless, the written subcorpus still shows a remarkably higher lexical diversification, i.e. a higher number of different lexical types for adverbs in -mente. Both in terms of tokens and types, adverbs in -mente are used more frequently in the written corpus than in the spoken one. On the other hand, AA show not only more tokens in the spoken subcorpus (see table 5), but also more different lexical types (see figure 4). Contrarily to -mente, very few AA are exclusively used in the written subcorpus and AA show the highest lexical differentiation in the spoken subcorpus. By contrast, regarding PA-adverbials, there seems to be a small inventory of 'stable' lexemes, most of which are used both in the written and the spoken subcorpus (see the bicoloured part for PA in figure 4).

Table 7 shows the type-token ratio, which differs depending on the code:

Table 7. Type-token ratio (tokens: types = ratio)

\begin{tabular}{c|ccc} 
& AA & -mente & PA \\
\hline spoken & $2,503: 63=39.73$ & $714: 96=7.44$ & $166: 19=8.73$ \\
written & $530: 37=14.32$ & $397: 126=3.15$ & $54: 17=3.18$
\end{tabular}

In the written subcorpus, the high number of different lexical types for adverbs in -mente leads to a low type-token-ratio (397 tokens for 126 types: thus, on average, 3 occurrences per every adverb in -mente of a certain lexical type in the written subcorpus, see table 7). This means that adverbs in -mente are especially productive, in terms of lexical differentiation, in written texts. On the other hand, regarding the number of tokens, the most frequent category in the spoken subcorpus are adjective-adverbs (see table 5), but those correspond to a very small sample of different lexical types (2,503 tokens for 63 types: thus, on average, 40 occurrences per lexical type for the AA-type in the spoken subcorpus, see table 7). Consequently, there are some few adjective-adverbs, which are used with extreme frequency in the spoken language (e.g. só, mesmo, bom). As for PA, the ratio is also influenced by the high token frequency of de novo (see table 8 for details), whereas the other PA-types are remarkably less frequent.

We observe two reasons for the high occurrence rate of adverbs in -mente in the written corpus: First, many adverbs in -mente, such as brilhantemente 'brilliantly', cientificamente 'scientifically', superficialmente 'superficially', sossegadamente 'quietly', and informalmente 'informally', are used only in written texts and most of them occur just once or twice (as noted above, see also the low type-token-ratio in table 7). Since informants wrote their texts after the oral interviews, these adverbs were added during the production of the texts. The elaboration of written texts thus favours the usage of a more diversified lexicon and especially adverbs in -mente as a certain style or a 
certain discursive tradition might request. Possibly, -mente is simply regarded as a necessary or appropriate marker for elaborate or educated written texts. Indeed, this was shown by Alarcón Neve (2019) for Mexican Spanish: school children learn and reproduce adverbs in -mente in certain formal text-types imitating model-texts from schoolbooks. ${ }^{10}$

Second, some adjective-adverbs may be transformed into -mente in written texts. For example, an informant uses só 'only' in the spoken interview but later, when writing the corresponding text, he prefers somente 'only': 11

(2) E: me conta uma história para nós... de uma coisa que tenha acontecido com alguém... que tenham te contado...

I: bom ... essa... essa é recente... eu tenho um amigo que... há três anos ele terminou... o segundo grau...e só o/esse ano que ele fez vestibular... né? (Vanderlei, m, 17, Informante do Ensino Médio (de 18 a 20 anos), 1993, Rio Grande, parte oral)

(3) Tenho um amigo que fazem três anos que terminou o $2^{\circ}$ grau, mas somente em 93 ele prestou vestibular. (ibidem, parte escrita)

In the $\mathrm{D} \& \mathrm{G}$ corpus, de novo 'again' is the most frequent PA-adverbial and the one that most clearly surpasses the corresponding alternative(s) (-mente and AA; see table 1): 132 tokens of de novo/49 novamente/0 novo; the other two PAadverbials meeting this criterion stem from the lexical groups 'leve' and 'vivo', i.e. de leve 'lightly' 4/levemente 1 /leve 1 and ao vivo 'live' 5/vivamente $0 / v i v o 1$. Table 8 shows the distribution of de novo and novamente in the written and spoken subcorpus:

Table 8. Frequency of de novo and novamente

\begin{tabular}{ccc|cc|cc}
\multicolumn{2}{c|}{ de novo } & \multicolumn{2}{c|}{ novamente } & \multicolumn{2}{c}{ sum } \\
\hline & tokens & ratio per 100,000 & tokens & ratio per 100,000 & tokens & ratio per 100,000 \\
\hline spoken & 112 & 36.91 & 30 & 9.88 & 142 & 46.79 \\
written & 20 & 24.53 & 19 & 23.31 & 39 & 47.84 \\
\hline total & 132 & 34.29 & 49 & 12.73 & &
\end{tabular}

\footnotetext{
${ }^{10}$ Another possible hypothesis, which could be further tested in the corpus, concerns education. One might state that informants with a higher educational level use more adverbs in -mente in their texts. Kortschak and Hummel (2018) showed that Spanish adverbs in -mente are more frequently used by speakers with higher educational level. In the D\&G corpus, Barbosa (2006) analysed the frequency of adjective-adverbs based on different educational levels the speakers. This data could be contrasted with the use of adverbs in -mente.

11 Examples (2) and (3) show, by the way, how the written text eliminates oral discourse markers (bom, né). Additionally, the introductory dialogues between informants and interviewers also considerably enlarge the size of the spoken corpus (see section 3).
} 
Whereas de novo is more frequent in spoken language than in written texts (see ratio per 100,000 words, 36.91 vs. 24.53), novamente is used more than twice as much in written texts than in the spoken interviews ( 9.88 vs. 23.31). Again, the difference between oral and written code is especially pronounced in the case of the adverb in -mente. As shown in table 8, in total, adverbs expressing 'again' are nearly as frequent in the spoken subcorpus as in the written one (ratio per 100,000 words: 46.79 spoken vs. 47.84 written). Instead, regarding the internal distribution in the subcorpus, de novo (112 tokens) is almost four times more frequent than novamente (30 tokens) in the spoken subcorpus, whereas in the written subcorpus both occur almost in an even number (de novo 20, novamente 19).

For example, the same informant uses de novo (3 tokens) in the spoken interview but, when writing about the same topic, he turns to novamente (1 token) in the same syntactic context:

(4) pra se pintar um carro tem que ter... plastique... que é uma massa branca... aí lixa... lixa com água... depois... lixa com lixa de ferro... depois com água... dá outra massa... que é a massa rápida... é uma massa preta... lixa com água de novo ... aí vai... dá um... dá um () vai... lixa de novo com água... aí... vai... pega... pega a tinta do carro... que vai ter... queima... dá uma tinta nele... queima... aí... dá repasse com a massa de novo ... pra tapar os... os defeitos... aí vai... lixa... dá outro repasse...aí vai com a tinta final... pinta... pega a pistola e pistola... e é só ... (Adilson, m, 18, Informantes do C.A. Supletivo, parte oral: relato de procedimento)

(5) Para pintar um carro é preciso uma lata de massa. Ela é branca. depois passo a no carro pega uma lixa de ferro e começa a lixar depois. pega a lixa de água e lixa tudo novamente. depois pega uma massa rápida e aplica no carro. tudo. pego a tinta e passo no carro lixo tudo e depois dou a tinta final. (ibidem, parte escrita: relato de procedimento)

\section{Conclusions}

In hypothesis 1 we argued that PA (adverbials formed by the pattern "preposition + adjective") are the least productive formation-type (compared to adjective-adverbs and adverbs in -mente). Indeed, the data shows that PA are less frequent - both in terms of types and tokens - than AA and -mente in present-day Brazilian Portuguese. This is confirmed both in the written and spoken subcorpora. Only one PA is used in a considerable manner (de novo), whereas the other forms are marginal.

In hypothesis 2 we stated that PA appear evenly in spoken and written language. In fact, regarding the frequencies in spoken and written code, there is no remarkable difference in the case of PA, since they occur almost equally in both 
subcorpora. They are only slightly more frequent in the written corpus, which at best can be considered tendentially still statistically significant. By contrast, adverbs in -mente show a clear preference for the written code (twice as many tokens in the written than in the spoken corpus) and AA - the most frequent formation-type in both subcorpora - is, statistically confirmed, more frequent in the spoken subcorpus. Furthermore, in the context of lexical diversification, most PA-types (lexical types) are used in both subcorpora, whereas adverbs in -mente are the most diversified in the written subcorpus and AA in the spoken one.

Both results may indicate that PA form a small inventory of lexicalised forms, which are equally used in written and spoken language. They are somewhat 'neutral' forms that are not marked for any code. PA would appear to be the least productive formation-type in the sense that few other forms than the documented ones might be expected to exist (contrarily to -mente).

\section{BIBLIOGRAPHY}

a) corpus:

Votre, Sebastião, Oliveira, Mariangela Rios de, Furtado da Cunha, Maria Angélica, Gerhalter, Katharina, 2020, "Corpus of Brazilian Portuguese Adjective-Adverbs, adverbs in -mente and Prepositional Phrases in Corpus Discurso \& Gramática", in Gerlinde Schneider, Christopher Pollin, Katharina Gerhalter, Martin Hummel, Adjective-Adverb Interfaces in Romance. Open-Access Database, <https://gams.uni-graz.at/o:aaif.ptapmdeg> [last access: 08/2020].

b) references:

Alarcón Neve, Luisa Josefina, 2019, "Usos de modificadores adjetivales y adverbiales en el discurso narrativo de escolares: $i$ qué tanto se apegan al modelo presentado en los libros de texto?", Keynote Talk at XXII Deutscher Hispanistentag (Berlin, 27-31/03/2019), Handout: <https://www.luisaalarconneve.com/blog/xxii-dh-29/03/2019> [last access: 08/2020].

Azevedo, Jaqueline Cristina Rocha Marcondes, 2018, "A multifuncionalidade do enfim", in Milena Torres de Aguiar, Monclar Guimãraes Lopes (eds.), Anais do XXII Seminário Nacional e IX Seminário Internacional do Grupo de Estudos Discurso \& Gramática, 1(1), Niterói, Letras da Universidade Federal Fluminese, p. 214-229.

Barbosa, Mariana Gonçalves, 2006, Gramaticalização de advérbios a partir de adjetivos: um estudo sobre os adjetivos adverbializados, Dissertação de Mestrado, Rio de Janeiro, Universidade Federal do Rio de Janeiro.

Basílio, Margarida, 2002, "Flutuação categorial de base adjetiva no português falado", in Rodolfo Ilari (ed.), Gramática do Português falado, Campinas, Editora da Unicamp, p. 75-90. 
Bauer, Brigitte, 2001, "Syntactic innovation in Latin poetry? The origins of the Romance Adverbial Formation in -ment(e)", in M.G.M. van der Poel, A. P. Orbán (eds.), Ad Litteras: Studies in Honour of J. H. Brouwers, Nijmegen, Nijmegen University Press, p. 29-43.

Bauer, Brigitte, 2003, "The adverbial formation in mente in Vulgar and Late Latin. A problem in grammaticalization", in Heikki Solin, Martti Leiwo \& Hilla Halla-aho (eds.), Latin tardif et latin vulgaire, IV, Hildesheim, Georg Olms Verlag, p. 439-457.

Bechara, Evanildo, 2009, Moderna Gramática Portuguesa, 37.a edição revista, ampliada e atualizada, Rio de Janeiro, Nova Fronteira.

Campos, Julia Langer de, 2019, A competição entre [verbo ADJETIVO ADVERBIAL] $e$ [verbo XMENTE] na rede construcional qualitativa do português brasileiro: uma análise centrada no uso, Tese de Doutorado, Universidade Federal do Rio de Janeiro, Rio de Janeiro.

Chircu, Adrian, 2006, "L'adverbe portugais. Description synthétique", in Philologica Jassyensia, 2(1), p. 23-30.

Chircu, Adrian, 2008, L'adverbe dans les langues romanes. Études étymologique, lexicale et morphologique (français, roumain, italien, espagnol, portugais, catalan, provençal), Cluj-Napoca, Casa Cărţii de Ştiinţă.

Company Company, Concepción (ed.), 2014a, Sintaxis histórica de la lengua española. Tercera parte: Adverbios, preposiciones y conjunciones. Relaciones interoracionales, México, Fondo de Cultura Económica \& Universidad Nacional Autónoma de México.

Company Company, Concepción, 2014b, "Adverbios en -mente", in Concepción Company Company (ed.), Sintaxis histórica de la lengua española. Tercera parte: Adverbios, preposiciones y conjunciones. Relaciones interoracionales, México, Fondo de Cultura Económica \& Universidad Nacional Autónoma de México, p. 459-614.

Coulmas, Florian, 2013, Writing and Society: an introduction, Cambridge, Cambridge University Press.

Furtado da Cunha, Maria Angélica, 2012, “A distribução do advérbio não nas orações negativas”, in Mariângela R. d. Oliveira, Maria M. Cezário (eds.), Adverbiais: Aspectos gramaticais e pressões discursivas, Niterói, Editora da Universidade Federal Fluminese, p. 243-264.

Gerhalter, Katharina, Hummel, Martin, Schneider, Gerlinde, Pollin, Christopher, 2018, "Compilation and Annotation of Adjective-Adverb Interfaces in Romance. Towards a multilingual Open Access Corpus", in CHIMERA: Romance Corpora and Linguistic Studies, 5(2), p. 305-311 <https://revistas.uam.es/index.php/chimera/article /download/9720/10133> [last access: 08/2020].

Grübl, Klaus, 2018, "La storia degli avverbi italiani in -mente: nuove prospettive sull'origine di un paradigma morfologico", in Martin G. Becker, Ludwig Fesenmeier (eds.), Configurazioni della serialità linguistica: Prospettive italoromanze, Berlin, Frank \& Timme Verlag, p. 31-48.

Hummel, Martin, 2014, "Adjetivos adverbiales", in Company Company, Concepción (ed.), Sintaxis histórica de la lengua española. Tercera parte: Adverbios, preposiciones y conjunciones. Relaciones interoracionales, México, Fondo de Cultura Económica \& Universidad Nacional Autónoma de México, p. 613-732. 
Hummel, Martin, 2017, “Existe a concordância adverbial no português brasileiro? Considerações acerca de vamos diretos, todas contentes, bastantes grandes, muitas boas", in Mariângela R. d. Oliveira, Maria M. Cezario (eds.), Funcionalismo linguístico: Diálogos e vertentes, Niterói, Editora da Universidade Federal Fluminese, p. 113-140.

Hummel, Martin, 2018, "Éléments d'une diachronie grammaticographique et normative de l'adverbe français: Accompagnés de trois méthodes pour mesurer l'effet du discours normatif sur l'usage", in Romanische Forschungen, 130(1), p. 3-35.

Hummel, Martin, 2019a, "The third way: Prepositional adverbials in the diachrony of Romance (Part One)”, in Romanische Forschungen 131(2), p. 145-185.

Hummel, Martin, 2019b, "The third way: Prepositional adverbials in the diachrony of Romance (Second and Last part)", in Romanische Forschungen, 131(3), p. 28-42.

Hummel, Martin, Chircu, Adrian, García Hernández, Benjamín, García Sánchez, Jairo Javier, Koch, Stefan, Porcel Bueno, David, Wissner, Inka, 2019, "Prepositional Adverbials in the Diachrony of Romance: A State of the Art", in Zeitschrift für romanische Philologie, 135(4), p. 1080-1137.

Koch, Peter, Oesterreicher, Wulf, 2011, Gesprochene Sprache in der Romania: Französisch, Italienisch, Spanisch, Tübingen, Max Niemeyer Verlag.

Koch, Stefan, Vecchia, Cesarina, "Locuzioni preposizionali con funzione avverbiale in un dialetto campano (Montellese)", (in prep.).

Kortschak, Carmen, Hummel, Martin, 2018, "Los adverbios en -mente en los registros formal e informal del español hablado peninsular y mexicano", in Nueva Revista de Filología Hispánica, 66(1), p. 3-43.

Maas, Utz, 2010, "Literat und orat. Grundbegriffe der Analyse geschriebener und gesprochener Sprache”, in Grazer Linguistische Studien, 73, p. 21-150.

Martelotta, Mário Eduardo, 2012, “Advérbios - conceito e tendências de ordenação", in Mariângela R. d. Oliveira, Maria M. Cezário (eds.), Adverbiais: Aspectos gramaticais e pressões discursivas, Niterói, Editora da Universidade Federal Fluminese, p. 13-96.

Ramos, Nice da Silva, 2018, "O aliás e seus valores semânticos em perspectiva funcional”, in Milena T. de Agiar, Monclar G. Lopes (eds.), Anais do XXII Seminário Nacional e IX Seminário Internacional do Grupo de Estudos Discurso \& Gramática, Niterói, Letras da Universidade Federal Fluminese, p. 58-76.

Raposo, Eduardo Paiva et alii (eds.), 2013, Gramática do Português, vol. I, Lisboa, Fundaçaõ Calouste Gulbenkian.

Sicherl, Eva, Žele, Andreja, 2015, "Combinability with prepositions in Slovene and English: theoretical and contrastive views", in Linguistica, 46(1), p. 209-226.

Silvestri, Giuseppina, 2017, "Adverb agreement in the dialects of the Lausberg Area", in Martin Hummel, Salvador Valera (eds.), Adjective adverb interfaces in Romance, Amsterdam-Philadelphia, John Benjamins Publishing Company, p. 173-204.

Valera, Salvador, Hummel, Martin, 2017, "Introduction”, in Martin Hummel, Salvador Valera (eds.), Adjective adverb interfaces in Romance, Amsterdam-Philadelphia, John Benjamins Publishing Company, p. 1-8.

Vidal, Rosângela Maria Bessa, 2009, As construções com adverbiais em "-mente": análise funcionalista e implicações para o ensino de língua materna, Tese de doutorado, Natal, Universidade Federal do Rio Grande do Norte. 